\title{
Ficus septica Burm. F. Leaves Ethanolic Extract Induces Apoptosis in 7, I 2-Dimethylbenz[A]Nthracene-Induced Rat Liver Cancer Quatitavely
}

\author{
Dita Brenna Septhea, Anindyajati, Andita Pra Darma, Ika Nurzijah, \\ Agung Endro Nugroho, and Edy Meiyanto* \\ Cancer Chemoprevention Research Center, Faculty of Pharmacy, Universitas Gadjah Mada, Yogyakarta \\ Jalan Sekip Utara Yogyakarta 55281 (Telp. 02746492662 Fax. 543120)
}

\begin{abstract}
The chemopreventive effect of Ficus septica Burm. f. leaves ethanolic extract (FLEE) was studied in 7,12-dimethylbenz[a]nthracene(DMBA)-induced rat liver cancer. Rats were divided into 5 group, 5 rats ( 5 wk of age Sprague Dawley rat) in each group. Group I was control diet group, administered with $0,5 \% \mathrm{CMC}-\mathrm{Na}$ as vehicle. FLEE was administered 750 $\mathrm{mg} / \mathrm{kgBW}$ and $1500 \mathrm{mg} / \mathrm{kgBW}$ starting $4 \mathrm{wk}$ until $5 \mathrm{wk}$ after DMBA administration at the first until fifth wk to group 2 and group 3 . Group 4 was control extract group, administered with $750 \mathrm{mg} / \mathrm{kgBW}$ and group 5 was DMBA group. DMBA is a carcinogen to induce liver cancer was also administered in DMBA control group and all animals were necropsied at 6 wk after DMBA administration. Activity of inducing apoptosis was detected using Double Staining method in $750 \mathrm{mg} / \mathrm{kgBW}$ FLEE group compared to control group but no in $1500 \mathrm{mg} / \mathrm{kgBW}$ FLEE group resulted in $100 \%$ dead. Apoptotic cells would have orange flourescence but normal cells would have green flourescence detected by flourescence microscope. To investigate the protein that involved in apoptotic mechanism, we studied p53 expression using Imunohistochemistry (IHC). There was no difference expression of $\mathrm{p} 53$ in both tested and control groups. Based on the results, FLEE has a potency as chemoprentive agent because its activity on inducing apoptosis in liver cancer with $\mathrm{p} 53$-independent pathway. The mechanism of apoptosis induction of this extract needs to be explored by observing the expression of related proteins.
\end{abstract}

Keywords: apoptosis, Ficus septica, liver cancer, p53 independent pathway

\section{INTRODUCTION}

Cancer known as a deadly disease that can avoid apoptosis, a programmed-cell-death, due to mutation of proapotosis regulator, p53 (Hanahan and Weinberg, 2000). Liver cancer ranks fifth among men and eighth among women worldwide and the insidence will increase until 2025 with the number of deaths is almost 598,000 (Garcia et al., 2007 and Parkin et al., 2005). Therefore, liver cancer is the third most common cause of death from cancer with survival rates are $3 \%$ to $5 \%$ in cancer registries for the United States and developing countries (Parkin et al., 2005). Worldwide, the major risk factors for liver cancer are infection with the hepatitis viruses, hepatitis B and $\mathrm{C}$, and consumption of foods contaminated with aflatoxin (Parkin et al. 1999). Both viruses confer a 20-fold increased risk of liver cancer (Donato et al., 1998).
Cancer has defects in the apoptotic regulatory pathways such as p53 (Kaufmann and Hengartner, 2001). Protein p53 contributes to apoptosis induced by a variety of cellular stress, including DNA damage, oxidative stress, and chemotherapeutic drugs (Steele et al., 1998). Cell death induced through the p53 pathway is executed by the caspase proteinases, which, by cleaving their substrates, lead to the characteristic apoptotic phenotype (Schuler anf Green, 2001). The understanding of apoptosis has provided the basis for novel targeted therapies that can induce death in cancer cells or sensitize them to established cytotoxic agents and radiation therapy (Ghobrial et al., 2005).

*Corresponding author e-mail: meiyan_e@ugm.ac.id 
Surgery, chemotherapy, radioteraphy and hormonal therapy use monoclonal antibody are the mothods that used to cancer treatment (Dolinsky and Hill-Kayser, 2011 and Mihajlovic, 2008). But, the treatments tend to show toxic side effects in normal tissues and also causing resistance in cancer cells (Tyagi et al., 2004 and Davis et al., 2003). Therefore, the drug development for cancer treatment especially for liver cancer based on natural product evolve to decrease side effects as chemopreventive agent.

Chemopreventive agents are compounds that able to prevent, to slow down, or to stop carcinogenesis (Tamimi et al., 2005). Phenantroindolicidine, an alkaloid found in $F$. septica, was proven to have cytotoxic activity against cancer cells (Staerk et al., 2002). FLEE showed cytotoxic activity and able to trigger apoptosis on T47D cell line (breast cancer) with $\mathrm{IC}_{50} 58 \mu \mathrm{g} / \mathrm{ml}$ (Nurcahya, 2007). Furthermore, Sekti et al. (2008) reported that FLEE performed synergist effect with doxorubicin against MCF7 (breast cancer) cell line with the $\mathrm{IC}_{50}$ value of 6 $\mu \mathrm{g} / \mathrm{ml}$ and was able to induce apoptosis by suppressing the expression of Bcl-2. Therefore, $F$. septica has potential effect as chemopreventive agent. Based on several research above, this study aimed to observe effect of FLEE on inducing apoptosis in vivo by increasing p53 expression in 7,12-dimethylbenz $[a]$ nthracene-induced rat liver cancer.

\section{MATERIALS AND METHODS}

\section{Location}

This study was conducted in the Laboratory of Cancer Chemoprevention Research Center, Faculty of Pharmacy and the Laboratory of Parasitology, Faculty of Medicine, Universitas Gadjah Mada, Yogyakarta.

\section{Plant Material}

Specimen of the same population of $F$. septica leaves were collected in January 2010 in Sleman, Yogyakarta, and identified in
Pharmacognocy Laboratory, Faculty of Pharmacy, Universitas Gadjah Mada, Yogyakarta.

\section{Extraction and Detection}

Fresh leaves of $F$. septica $(12 \mathrm{~kg})$ were ground to a coarse powder $(523 \mathrm{~g})$ and macerated with 5,23 L 70\% ethanol (E. Merck) (1:10) at room temperature for 3 days and shaked twice a day (morning and afternoon) for 5 minutes. The ethanolic extract were filtered and concentrated under reduce pressure to yield $22,67 \mathrm{~g}$ of concentrated extract (less than $10 \%$ water in extract).

\section{Animals}

A total of 25 female Sprague Dawley Rats (5 weeks old), weighed from 86 to $112 \mathrm{~g}$ were purchased from Unit Pengembangan Hewan Percobaan Universitas Gadjah Mada. The animals were kept for at least one week before use, and the rats were given standard pellet diet and water $a d$ libitum, and kept on a 12:12 h light/dark cycle.

\section{Experimental Procedure}

All animals was divided into 5 groups, 5 rats in each group. The experimental design is summarized in Table I. Beginning at $5 \mathrm{wk}$ of age, while animal where ini control diet (group 1) was administered with $0,5 \% \mathrm{CMC}-\mathrm{Na}$, groups of animal (group 2, 3, and 4) intended for carcinogen were treated per oral with single dose of DMBA (Sigma) $(20 \mathrm{mg} / \mathrm{kgBW})$, twice a week for 5 weeks. DMBA was dissolved in corn oil and FLEE extract was dissolved in 0,5\% CMC-Na as vehicle. Group 2 and group 3 was administered once a day by 750 $\mathrm{mg} / \mathrm{kgBW}$ and $1500 \mathrm{mg} / \mathrm{kgBW}$ for 2 weeks, starting 4 until 5 wk after DMBA administration. Group 5 was adiministered once a day by 750 $\mathrm{mg} / \mathrm{kgBW}$ for 2 weeks, starting 4 wk until 5 wk after DMBA administration in other groups.

Body weight were recorded weekly troughout the study. At 6 wk after DMBA administration, all animals were sacrified by ether as scheduled. At autopsy, liver organ were removed and fixed in $10 \%$ buffered formalin. After 12-24 $\mathrm{h}$ of fixation, 3-5 $\mu \mathrm{m}$ tissue slices were embedded in paraffin. 
Table I. Experimental design

\begin{tabular}{|c|c|c|c|}
\hline Experimental group & $\begin{array}{l}\text { Female Sprague } \\
\text { Dawley rats/group }\end{array}$ & $\begin{array}{l}\text { DMBA or CMC- } \\
\text { Na dosage/animal }\end{array}$ & Dose Frequency \\
\hline I. Control diet & 5 & $\begin{array}{c}0,5 \% \text { CMC-Na }(I \\
\mathrm{ml} / 200 \mathrm{gBW})\end{array}$ & $\begin{array}{c}\text { Once a day, starting } 4 \text { wk until } 5 \\
\text { wk after DMBA administered in } \\
\text { other groups }\end{array}$ \\
\hline 2. FLEE, $750 \mathrm{mg} / \mathrm{kgBW}$ & 5 & $20 \mathrm{mg} / \mathrm{kgBW}$ DMBA & $\begin{array}{l}\text { DMBA: twice a week, starting } \\
\text { first until fifth wk. FLEE: once a } \\
\text { day starting } 4 \text { until } 5 \text { wk after } \\
\text { DMBA administered }\end{array}$ \\
\hline 3. FLEE $1500 \mathrm{mg} / \mathrm{kgBW}$ & 5 & $20 \mathrm{mg} / \mathrm{kgBW}$ DMBA & $\begin{array}{l}\text { DMBA: twice a week, starting } \\
\text { first until fifth wk. FLEE: starting } 4 \\
\text { until } 5 \text { wk after } \\
\text { administered }\end{array}$ \\
\hline 4. $\quad$ DMBA, $20 \mathrm{mg} / \mathrm{kgBB}$ & 5 & $20 \mathrm{mg} / \mathrm{kgBW}$ DMBA & $\begin{array}{l}\text { DMBA: twice a week, starting } \\
\text { first until fifth wk. }\end{array}$ \\
\hline $\begin{array}{l}\text { 5. Control FLEE, } 750 \\
\mathrm{mg} / \mathrm{kgBW}\end{array}$ & 5 & - & $\begin{array}{l}\text { Once a day, starting } 4 \text { wk until } 5 \\
\text { wk after DMBA administered in } \\
\text { other groups }\end{array}$ \\
\hline
\end{tabular}

\section{Flourescence Microscopy}

Cell damage was assessed by monitoring changes in cell granularity by Double Staining with a combination of the fluorescent DNAbinding dyes acridine orange and ethidium bromide that allowed a quantitative determination of the cells (Baskic' et al., 2006). Sections were stained with $0,01 \%(\mathrm{w} / \mathrm{v})$ acridine orange (Sigma) and $0,01 \%(\mathrm{w} / \mathrm{v})$ ethidium bromide (Sigma) in 10 $\mathrm{mM}$ PBS buffer (pH 7,0) for $10 \mathrm{~min}$. Using this double staining, 2 types of nuclei were identified: (1) green nuclei in non-damaged cells and (2) apoptotic cells with a uniformly orange to red nucleus.

\section{Protein p53 Immunohistochemical Detection}

Tumor section were de-paraffinizied with xylene and dehydrated with ethanol (Merck). The slides were then immersed in water for $1 \mathrm{~min}$. For antigen retrieval, the slides were boiled in citrate buffer ( $\mathrm{pH}$ 6.0) for $15 \mathrm{~min}$ in a microwave and subsequently cooled for $20 \mathrm{~min}$. The slides was washed in phosphate-buffered saline (PBS) $(\mathrm{pH}$ 7.4), and endogenous peroxidase was then blocked by $0.3 \%$ hydrogen peroxide for $15 \mathrm{~min}$. After washing with PBS, the sections were incubated at $25{ }^{\circ} \mathrm{C}$ with anti-p53, Ab-1/Clone Pab 240 (Neomarkers) for $10 \mathrm{~min}$. The slide were washed with $\mathrm{PBS}$ and then the section were incubated at $25^{\circ} \mathrm{C}$ horse radish peroxidase as secondary antibody for $10 \mathrm{~min}$. After washing with PBS, the slides were incubated for $10 \mathrm{~min}$ at $25^{\circ} \mathrm{C}$ with diaminobenzidine (DAB) and finally counter-stained with hematoxylin eosin before mounting.

\section{Analysis}

For the qualitative analysis of apoptosis, the slides were examined using an flouresescence microscope (Nikon, Japan) and photographed using an digital camera (Canon, IXY Digital 25 IS 10,0 Megapixels, Japan). Non-damaged cells emit green flouresescence and apoptotic cells emit orange to red fluorescence. Apoptotic formations were assessed by fluorescence microscopy at a magnification of $\times 100$. The presence of protein p53 expression was determine using an light microscope (Nikon, Japan) and photographed using an digital camera (Canon, IXY Digital 25 IS 10,0 Megapixels, Japan).

\section{RESULTS AND DISCUSSION}

\section{General Observation}

There was no direct evidence of toxicity due to FLEE treatment however administration of $1500 \mathrm{mg} / \mathrm{kgBW}$ FLEE resulted 100\% dead. Body weight animal treated with DMBA and fed the control and experimental diets were comparable. Similarly, there were no differences in body weights of animals treated with vehicle, DMBA control (positive control) group, FLEE control group, and both treatment group (data not shown). Morfologycally, there were no macroscopic differences in liver organ of all rats (Fig. 1).

\section{Detection of Apoptosis}

The result obtained with acridine orange/ethidium bromide (AO/EB) double staining are presented in Fig. 2. The data showed that the percentage of apoptotic cells of administration of $20 \mathrm{mg} / \mathrm{kgBW}$ DMBA followed 
by $750 \mathrm{mg} / \mathrm{kgBW}$ FLEE has more orange to red nucleus compared to control group. There were a few orange to red nucleus were detected in control $750 \mathrm{mg} / \mathrm{kgBW}$ FLEE. Therefore, $750 \mathrm{mg} / \mathrm{kgBW}$

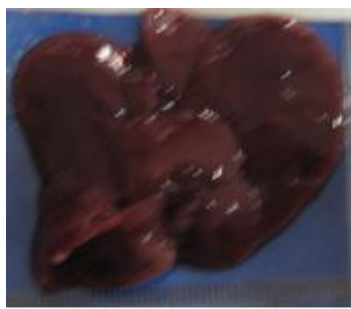

(a)

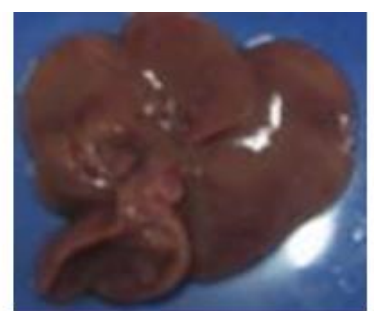

(b)

FLEE induced apoptosis in 7,12dimethylbenz $[a]$ nthracene-induced rat liver cancer.

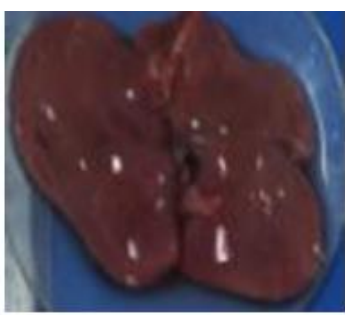

(c)

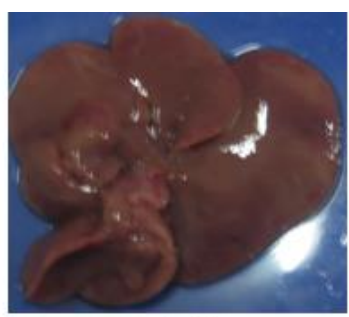

(d)

Figure I. Similar morfologically of liver treated with Ficus septica Burm. f. ethanolic extract (FLEE) in 7, I 2-dimethylbenz[a]nthracene-induced rat liver cancer. Rats were divided into 5 groups, 5 rats ini each group. (a) DMBA control group: administered with $20 \mathrm{mg} / \mathrm{kgBW}$ in corn oil; (b) treatment group: treated with $750 \mathrm{mg} / \mathrm{kgBB}$ FLEE; (c) FLEE control group: administered with $750 \mathrm{mg} / \mathrm{kgBB}$ FLEE; (d) control diet group: administered with 0,5\% CMC-Na (I ml/200mgBW). All rats were sacrified in 6 wk after DMBA administration. At autopsy, liver organ were removed and fixed in $10 \%$ buffered formalin.

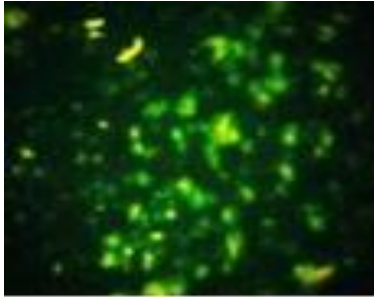

(a)

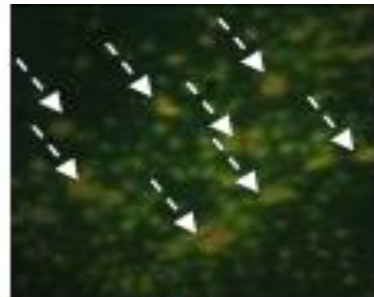

(b)

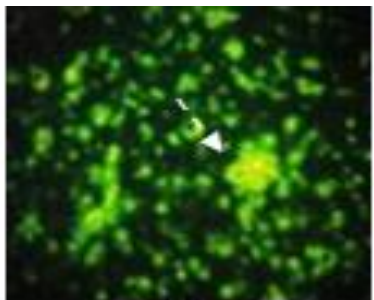

(c)

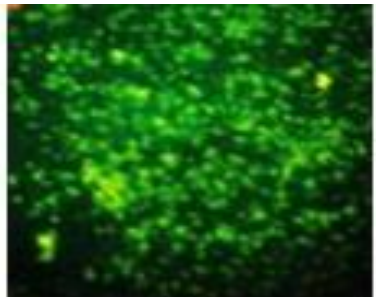

(d)

Figure 2. Ficus septica Burm. f. ethanolic extract (FLEE) induce apoptosis liver cells in 7,12dimethylbenz [a]nthracene-induced rat liver cancer. Rats were divided into 5 groups, 5 rats ini each group. (a) DMBA control group: administered with $20 \mathrm{mg} / \mathrm{kgBW}$ in corn oil; (b) treatment group: treated with $750 \mathrm{mg} / \mathrm{kgBB}$ FLEE; (c) FLEE control group: administered with $750 \mathrm{mg} / \mathrm{kgBB}$ FLEE; (d) control diet group: administered with 0,5\% CMC-Na (I $\mathrm{ml} / 200 \mathrm{mgBW})$. All rats were sacrified in 6 wk after DMBA administration. At autopsy, liver organ were removed and fixed in $10 \%$ buffered formalin. Tissue slices were embedded in paraffin. Apoptosis was identified use acridine orange and ethidium bromide in $10 \mathrm{mM}$ PBS buffer $(\mathrm{pH}$ 7,0) for $10 \mathrm{~min}$. The slides were examined using an flouresescence microscope and photographed using an digital camera. Apoptosis cells was signed by white arrows.

\section{Detection of protein p53 expression}

In this system, all brown-stained nuclei of liver cells were classified as positive regardless of staining intensity. As shown in Fig. 3, there was no difference of p53 expression between administration of $20 \mathrm{mg} / \mathrm{kgBW}$ DMBA followed by $750 \mathrm{mg} / \mathrm{kgBW}$ FLEE and control group, indicated from the intensity of brown area in cytoplasm.
High intensity of brown area sign high expression of p53. Therefore, administration of $750 \mathrm{mg} / \mathrm{kgBW}$ FLEE had no relation with p53 expression on inducing apoptosis. The apoptosis mechanism could be p53 independent pathways and this study should be more explored to know certain or related proteins. 


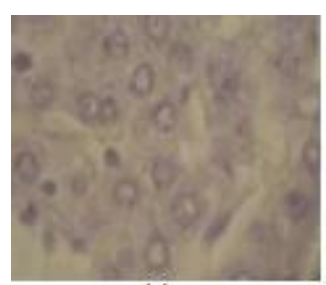

(a)

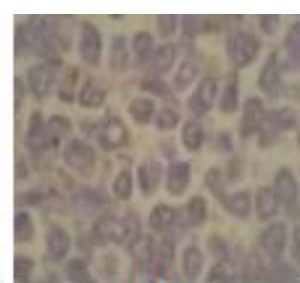

(b)

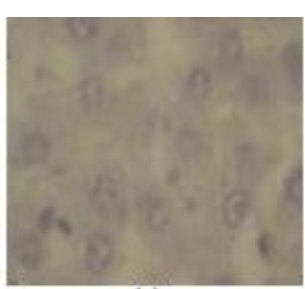

(c)

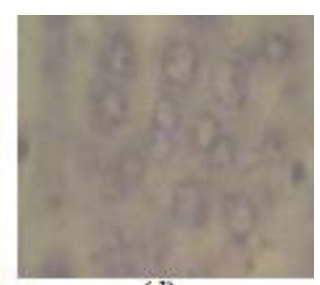

(d)

Figure 3. Ficus septica Burm. f. ethanolic extract (FLEE) have no effect in activation of p53 in liver cells in 7,12-dimethylbenz [a]nthracene-induced rat liver cancer. Rats were divided into 5 groups, 5 rats ini each group. (a) DMBA control group: administered with $20 \mathrm{mg} / \mathrm{kgBW}$ in corn oil; (b) treatment group: treated with $750 \mathrm{mg} / \mathrm{kgBB}$ FLEE; (c) FLEE control group: administered with $750 \mathrm{mg} / \mathrm{kgBB}$ FLEE; (d) control diet group: administered with 0,5\% CMC-Na (I ml/200mgBW). All rats were sacrified in 6 wk after DMBA administration. At autopsy, liver organ were removed and fixed in $10 \%$ buffered formalin. Tissue slices were embedded in paraffin. p53 expression was detected use Imunohistochemistry (IHC) and were incubated at $25{ }^{\circ} \mathrm{C}$ with anti-p53, Ab-I/Clone Pab 240 for 10 min. The slides were examined using an light microscope and photographed using an digital camera.

Understanding that somatic cells are born by mitosis and almost all will die by apoptosis, a physiological process of cellular suicide is critical for homoestasis mechanism. Cancers can occur when this balance is disturbed, either by an increase in cell proliferation or a decrease in cell death (Gerl and Vaux, 2005). The goal of cancer therapy is to promote the death of cancer cells without causing too much damage to normal cells. The knowledge of the mechanisms of apoptosis has enhanced our understanding of how some cancers originate and progress. Existing cancer therapies can work in two ways, by induction of apoptosis as well as by direct toxicity.

In general observation, there were no differences in body weights of animals treated with vehicle, DMBA control (positive control) group, FLEE control group, and both treatment groups. The similar morphology of liver organ in all rats indicate that, cancer had not grown yet macroscopically but, the macroscopically showed different. The morphologically difference indicate that cancer still in early stage.

Using Double Staining method with acridine orange-ethidium bromide, we detected apoptosis existing in cells. Qualitative analysis was done by using a fluorescence microscope. The result showed that $750 \mathrm{mg} / \mathrm{kgBW}$ F. septica leaves ethanolic extract (FLEE) induced apoptosis in 7,12-dimethylbenz $[a]$ nthracene-induced rat liver cancer. On the otherhand, all rats of 1500 $\mathrm{mg} / \mathrm{kgBW}$ FLEE treated group were died. It might happen that $1500 \mathrm{mg} / \mathrm{kgBW}$ FLEE was a toxic doses because all rats had got diarhea and died.

Basically, the apoptotic pathway is triggered off by two different signals, one extrinsic, which responds mainly to extracellular stimuli, and the other intrinsic, activated by modulators within the cell itself. In the intrinsic pathway, one of proteins that plays in role of induction of growth arrest or cell death is p53. With regard to the extrinsic pathway, the activation of the receptors belonging to the TNF family. Using Imunohistochemistry (IHC) which may identify specific protein, in this study is p53 in the cell or tissue by antibody-labeling to know the apoptosis pathway. It showed that 750 $\mathrm{mg} / \mathrm{kgBW}$ FLEE can induce apoptosis without affecting p53 activation because there was no difference of p53 expression compared to control group. This study might conclude that, the apoptosis pathway throught p53 independent pathway commit TNF family (Fas/Apo1, TNFR1, DR3/ TRAMP/Apo3, DR4/TRAILR1/Apo2, DR5/TRAILR2 and DR6/TR7), by means of specific ligands (TNF-a, TNF-b, TRAIL, FasL, etc), bring about the recruitment of the TNFR (Fas associated death domain) and TRADD (TNFR associated DD) family members and the chain activation of the caspases 8, 3 e 7 (Dempsey, 2003). But, the expression of related protein should be more identified.

\section{CONCLUSION}

Based on this study, Ficus septica Burm. f. ethanolic extract was able to induce apoptosis throught p53 independent pathway in 7,12dimethylbenz $[a]$ nthracene-induced rat liver cancer.

\section{ACKNOWLEDGEMENT}

We acknowledge the contributions and support of DIKTI and Cancer Chemoprevention Research Center (CCRC) of Faculty of Pharmacy, Universitas Gadjah Mada. 


\section{REFERENCES}

Davis, J.M., Navolonic, P.M., Weinstein, C.R., Steelman, L.S., Hu, Konovlepa, M., Blagosklonny, M.V. and McCubrey, J.A., 2003, Raf- $\mathrm{I}$ and $\mathrm{Bcl}-2$ induce distinct and common pathway that contribute to cancer drug resistance, Clin Cancer Res., 9(3), I I6I-70.

Dempsey, P.W., Doyle, S.E., He, J.Q. and Cheng, G., 2003, The signaling adaptors and pathways activated by TNF superfamily, Cytokine Growth Factor., 14, 193-209.

Dolinsky, C., 20II, Breast Cancer: The Basics. Available from: URL: http://www.oncolink.org/types/article.cfm?c= $3 \& s=5 \& s s=33 \& i d=8320 \&$ CFID $=2052956$ $8 \& C F T O K E N=66709214, \quad$ Accessed February 5, $201 \mathrm{I}$.

Donato, F., Boffetta, P. and Puoti, M.A., 1998, A meta-analysis of epidemiological studies on the combined effect of hepatitis B and $C$ virus infections in causing hepatocellular carcinoma, Int J Cancer., 75(3), 347-354.

Garcia, M., Jemal, A., Ward, E.M., Center, M.M., Hao, Y., Siegel, R.L. and Thun, M.J., 2007, Global Cancer Facts and Figures 2007, Atlanta, GA: American Cancer Society.

Gerl, R. and Vaux, D.L., 2005, Apoptosis in development and treatment of cancer. Carcinogenesis, 26(2), 263-270.

Ghobrial, I.M., Witzig, T.E. and Adjei, A.A., 2005, Targeting apoptosis pathways in cancer therapy, CA Cancer J Clin., 55, I78-94.

Hanahan, D. and Weinberg, R.A., 2000, The Hallmark of Cancer, Cell, I O0(I), 57-70.

Kaufmann, S.H. and Hengartner, M.O., 200I, Programmed cell death: alive and well in the new millennium, Trends Cell Biol., I I, 526-34.

Mihajlovic, M.L., 2008, Recent Advances in Radiation Therapy of Cancer Cells: A Step towards an Experimental dan Systems Biology Framework, Current Radiopharmaceuticals, Yugoslavia, Bentham Science Publishers Ltd.
Nurcahya, B.M., 2007, Efek Antiproliferatif Ekstrak Etanolik Daun Awar-Awar (Ficus septica Burm. f.) terhadap Sel Kanker Payudara T47D, Undergrad Thesis, Yogyakarta, Universitas Gadjah Mada, Departement of Pharmacy.

Parkin, D.M., Pisani, P. and Ferlay, J., 1999, Global cáncer statistic, CA Cancer J Clin., 49, 3364.

Parkin, D.M., Bray, F., Ferlay, J. and Pisani, P., 2005, Global cancer statistics, 2002, CA Cancer J Clin., 55(2), 74-108.

Schuler, M. and Green, D.R., 200I, Mechanism of p53-dependent apoptosis, Biochemical Society Transaction, 29(6), 684-688.

Sekti, D.A., Mubarok, M.F. and Wulandari, A., 2008, Upaya Peningkatan Aktivitas Sitotoksik Doxorubisin pada Sel Kanker Payudara MCF-7 Menggunakan Ekstrak Etanolik Daun Awar-Awar (Ficus Septica Burm. f.) serta Studi Docking Molekuler Alkaloid Fenantroindolisidin sebagai Inhibitor Raf-I, Proceeding of Kongres IImiah XVI ISFI 2008. Yogyakarta.

Staerk, D., Lykkeberg, A.K, Christensen, J., Budnik, B.A., Abe, F. and Jaroszewski, J. W., 2002, In Vitro Cytotoxic Activity of Phenanthroindolizidine Alkaloids from Cynanchum vincetoxicum and Tylophora tanakae against Drug-Sensitive and Multidrug Resistant Cancer Cells, J. Nat. Prod., 65, 1299-1302.

Steele, R.J, Thompson, A.M., Hall P.A. and Lane, D.P., 1998, The $\mathrm{p} 53$ tumor suppressor gene, Br. J. Surg., 85, I460-I 467.

Tamimi, R.M., Lagiou, P., Adami, H. and Trichopoulo, D., 2002, Prospect for Chemopreventionof Cancer, Canc Contr J., 4(2), 55-64.

Tyagi, A.K., Agarwal, C., Chan, D.C.F. and Agarwal R. 2004. Synergistic anti-cancer effects of silibinin with conventional cytotoxic agents doxorubicin, cisplatin dan carboplatin against human breast carcinoma MCF-7 dan MDA-MB468 cells, Oncol Rep., I I (2), 493-9. 